\title{
THREE NEW LEPANTHES (ORCHIDACEAE: PLEUROTHALLIDINAE) FROM THE ALTO DE VENTANAS ECOREGION IN ANTIOQUIA, COLOMBIA
}

\author{
Sebastián Vieira-Uribe ${ }^{1-4} \&$ Juan Sebastián Moreno ${ }^{3}$ \\ ${ }^{1}$ Sociedad Colombiana de Orquideología, Medellín, Colombia \\ ${ }^{2}$ Grupo de Investigación en Biodiversidad Tropical - GIBIOT, Jardín Botánico de Medellín, Colombia \\ ${ }^{3}$ Grupo de Investigación Schultes, Fundación Ecotonos, Cali, Colombia \\ ${ }^{4}$ Author for correspondence: utricseb@gmail.com
}

\begin{abstract}
Three new species of the genus Lepanthes from the Alto de Ventanas ecoregion in the central Andes of Antioquia, Colombia, are described and illustrated. Lepanthes sabinadaleyana is similar to $L$. lycocephala but it is distinguished by the narrowly ovate leaves and the lip with oblong-obovate blades with an ovoid, obtuse appendix. Lepanthes cissyana is similar to L. ballatrix, but it differs by its purple lip with elliptical blades and a semicircular, concave body with two long, pubescent appendices in the sinus. Lepanthes dougdarlingii is similar to L. hortensis but can be distinguished by the prolific habit and the appendix of the lip lingulate to oblong, pubescent, with a concave depression in the middle, an apical gland-like structure and a tuft of hairs on the abaxial surface near the apex.
\end{abstract}

KeY Words: Lepanthes cissyana, L. dougdarlingii, L. sabinadaleyana, orchid conservation, Salvamontes

Introduction. Taxonomy plays an important role in many different disciplines of biology, providing us the universal naming and classification system of biodiversity for centuries (Costello et al. 2015). It also allows us to know the number of living species on our planet and their biological characteristics (Dubois 2003). However, our inventory of living organisms is still incomplete, and many times limited by the lack of financial government support because frequently, budgets are assigned for conservation efforts in wellexplored areas and also, many conservationists and ecologist think that our current taxonomic survey of biodiversity is largely satisfactory (Dubois 2003). That is why taxonomy and conservation need a stronger bond where they can go hand-in-hand.

In Colombia, Orchidaceae is the most diverse family of plants with more than 4,000 species (Bernal et al. 2015), which are found abundantly in virtually every natural ecosystem with its highest richness in the Andes (Luer \& Thoerle 2012). Its taxonomy is not always easy due to the high number of species, their wide and localized distribution, the phenotypic variations among species, and the constant changes within phylogenies. Orejuela (2012) stated that orchid conservation has to be multi-faceted, combining the protection of the habitat with the coordination of both in-situ and ex-situ efforts, the involvement of communities in species and ecosystem conservation projects, outreach activities, and the creation of knowledge networks, increasing education about species and their distribution. This is undoubtedly the only way to route the orchid conservation to its salvation in years to come.

One of the most effective strategies to promote biodiversity conservation is by strengthening systems of national parks and similar reserves at regional (departmental) and local levels, integrating protection of species and ecosystems (Orejuela 2012). In recent years, different efforts have been undergoing in Colombia for the creation of private natural reserves motivated fully or partially by the presence of endangered and rare orchid species. One of these initiatives is the one being developed by Corporación Salvamontes Colombia since early 2016, in the Alto de Ventanas eco-region in the central Andes of Antioquia, with the help of the Orchid Conservation Alliance and the Rainforest Trust. Three natural reserves are now in place, and some of the biggest forest remnants in the region are now preserved inside them, thus protecting the habitat for many rare and endangered orchids. 
The Alto de Ventanas region was explored for orchids during the ' 80 s by Carl Luer and Rodrigo Escobar where they found several new species in the Pleurothallidinae, most of them in the genus Lepanthes Sw. (Luer \& Escobar 1984, 1984a, 1984b, $1984 \mathrm{c}$ ), and so far, known only from that area. While exploring the region for the assessment of orchid species inside the Salvamontes natural reserves we found many Lepanthes species, some of them already known, and some that are new to science including the novelties here described.

As part of the mentioned conservation efforts, some of the lands purchased for the expansion of one of the Salvamontes natural reserves were funded by auctioning the names of the three new species described here with the help of the Rainforest Trust. That is a good example and only one of the possible ways where taxonomy and conservation work hand in hand for the protection of orchid habitats.

\section{TAXONOMIC TREATMENT}

Lepanthes sabinadaleyana J.S.Moreno \& S.VieiraUribe, sp. nov. Fig. 1-4A.

TYPE: Colombia. Antioquia: Municipality of Valdivia,

Ventanitas, La Esperanza Natural Reserve, 2150 m, 2 Aug. 2017. J. S. Moreno 519, A. L. Erazo \& S. Vieira (holotype: JAUM; isotype: CAUP).

DiAGNosis: Lepanthes sabinadaleyana is most similar to L. lycocephala Luer \& R.Escobar, both bearing small reddish flowers with longitudinally concave lip blades with everted apices, but the lip in L. sabinadaleyana has oblong-obovate blades with an ovoid, obtuse appendix.

Plant epiphytic, sympodial, caespitose herb up to $9 \mathrm{~cm}$ tall. Roots ca. $0.7 \mathrm{~mm}$ in diameter. Ramicauls slender, erect to horizontal, elongated, thin, 7-12 cm long, enclosed by 6-11 microscopically scabrous, tightly fitting acuminate lepanthiform sheaths. Leaf green, thinly coriaceous, narrowly ovate, acute, attenuate, $3.0-3.5 \times 0.7-0.8 \mathrm{~cm}$, the base broadly cuneate, contracted into a petiole ca. $2 \mathrm{~mm}$ long. Inflorescence a congested, distichous, successively flowered raceme up to $7 \mathrm{~mm}$ long, borne by a filiform peduncle 11-12 mm long, resting on the adaxial surface of the leaf. Floral bracts spiculate,
$1 \mathrm{~mm}$ long; pedicels $1.5 \mathrm{~mm}$ long. Ovary costate, 1.5-1.7 mm long. Flower with sepals translucent rose, petals, column and lip rose, anther cap white, suffused with rose. Sepals similar in shape and size, carinate along the veins on the abaxial surface; dorsal sepal ovate, cuspidate, slightly concave, 3-veined, $4.0 \times 2.5 \mathrm{~mm}$, connate to the lateral sepals for $0.5 \mathrm{~mm}$; lateral sepals connate $1.5 \mathrm{~mm}$ into a broadly ovate bifid synsepal, $3.0-3.5 \times 3.5 \mathrm{~mm}$, each individual sepal free for $c a .1 \mathrm{~mm}, 2$-veined with the apices cuspidate. Petals transversely bilobed, pubescent, shallowly retuse at the apex between the two lobes, $0.5 \times 2.5 \mathrm{~mm}$, the upper lobe triangular, deflexed, acute, $1.5 \mathrm{~mm}$ long, the lower lobe triangular, subacute, $1 \mathrm{~mm}$ long. Lip bilaminate, the blades diverging, thickened towards the apex, pubescent, oblong-obovate, longitudinally concave, $1.5 \mathrm{~mm}$ long with everted, rounded apices; the connectives $c a .0 .5 \mathrm{~mm}$ long, cuneate; the body triangular when expanded, adnate to the base of the column; the appendix ovoid, pubescent, glandular and rounded at the apex. Column terete, $1.5 \mathrm{~mm}$ long, the anther and stigma apical. Pollinia 2, pyriform, attached to a detachable viscidium, $0.5 \mathrm{~mm}$ long. Anther cap cucullate, $0.5 \mathrm{~mm}$ long. Capsule $4.2 \mathrm{~mm}$ long.

Eponymy: Name after Sabina Daley, a graphic designer, mom, and orchid enthusiast. She lives in New York City, but her dreams often take her to the rainforests where orchids grow. The right to name this species was given to Adam Deaton, who generously donated land purchase funds for the expansion of the natural reserves where the species was found.

HabitAT AND ECOlOGY: Numerous plants of this species have been observed growing at two nearby locations (less than $3 \mathrm{~km}$ apart) inside the "Alto de Ventanas" Integrated Management District at 2000-2200 m elevation. Individuals from both populations were growing together with other small pleurothallids on moss-covered low twigs and branches (Fig. 2C) of shrubs and trees growing close to water streams or in swampy, sphagnum covered soil, inside remaining patches of forest or old shrubland. The plants are usually shaded or partially exposed to the sun, and where found, tend to be the most abundant species of Lepanthes. It has been found growing near, or together 


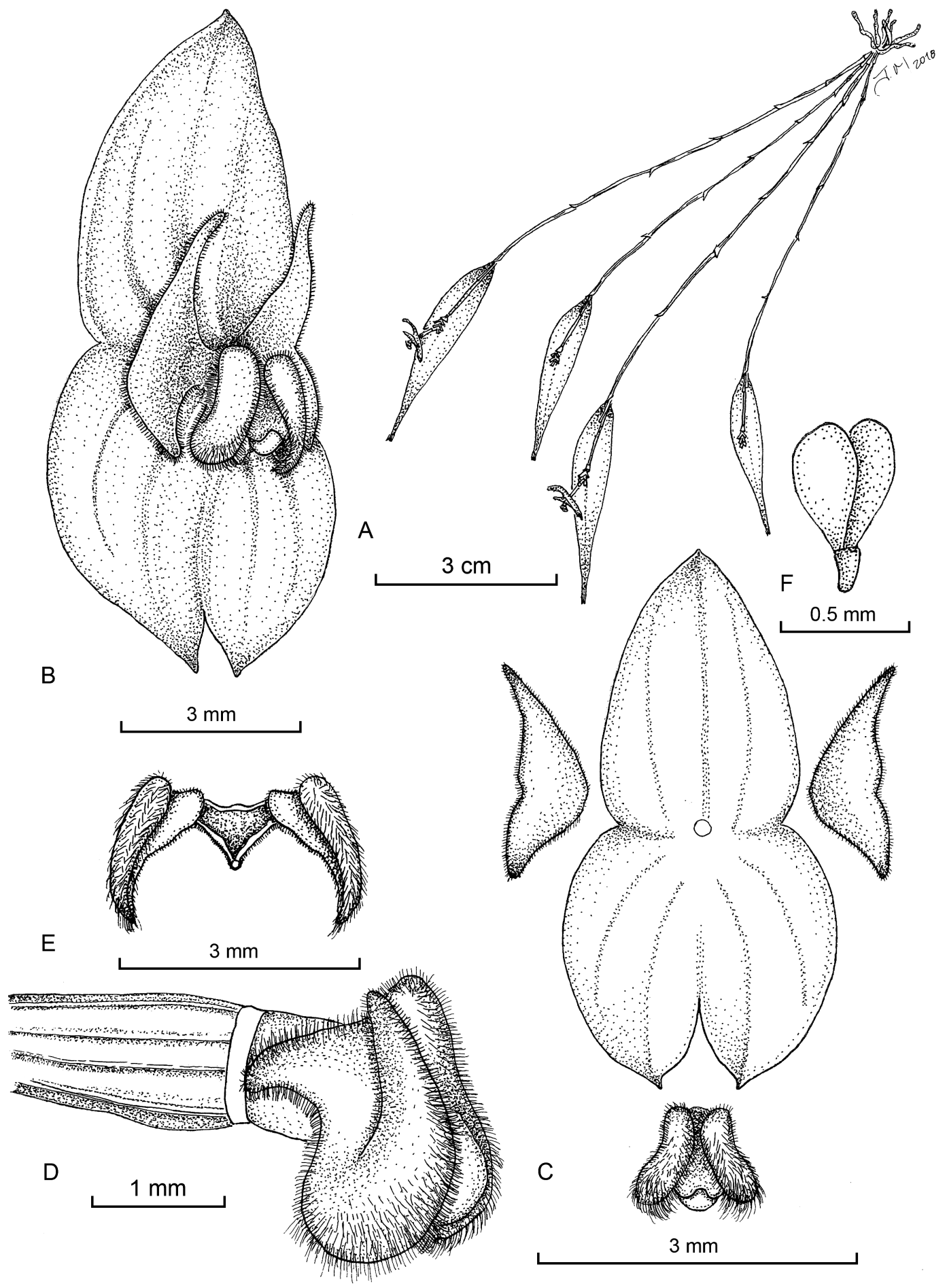

Figure 1. Lepanthes sabinadaleyana J.S.Moreno \& S.Vieira-Uribe. A. Habit. B. Flower. C. Dissected perianth. D. Ovary, column and lip, side view. E. Lip in expanded position. F. Pollinia. Drawn by Juan Sebastián Moreno from the plant that served as type. 


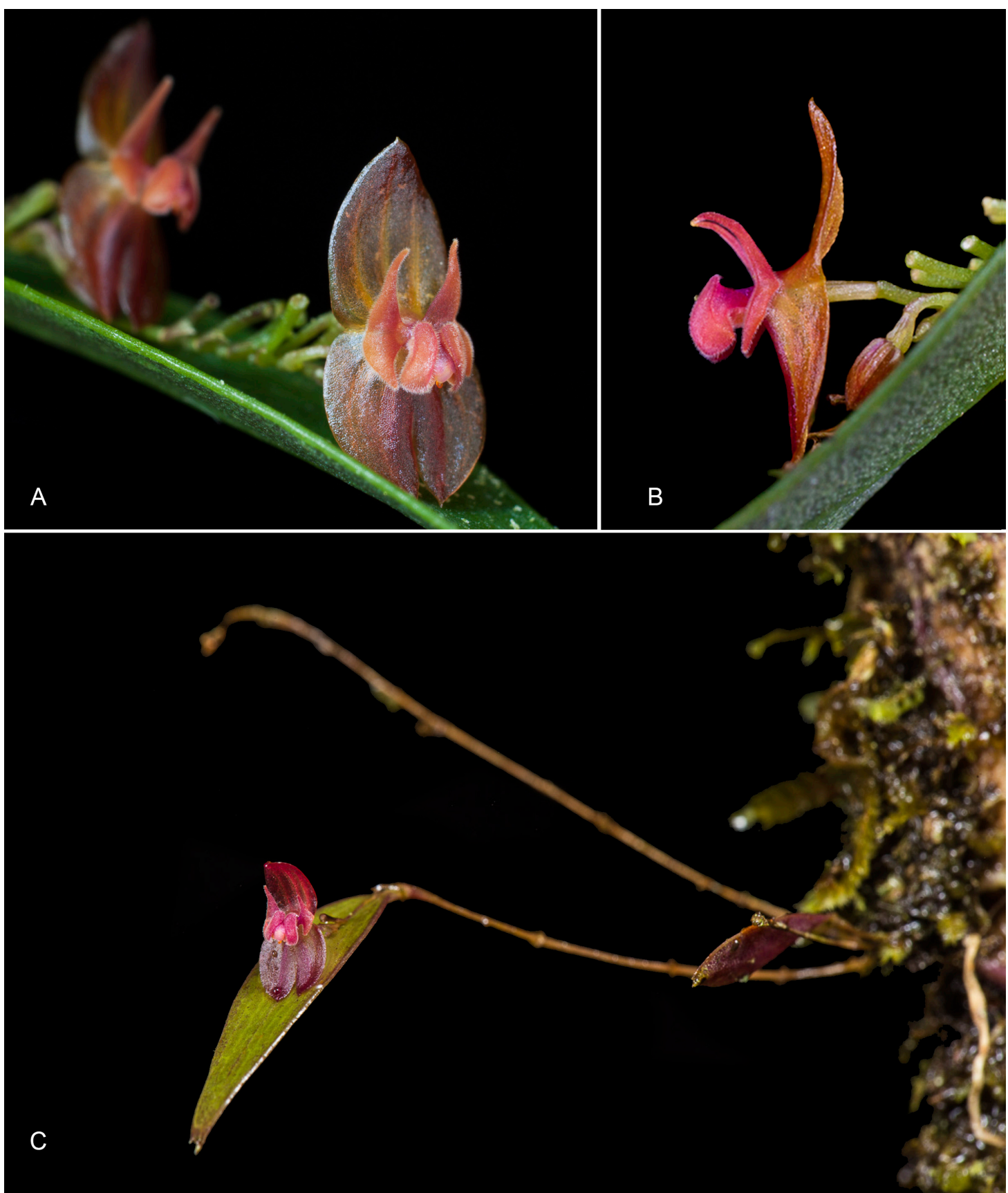

Figure 2. Lepanthes sabinadaleyana J.S.Moreno \& S.Vieira-Uribe. A. Flower, oblique view. B. Flower, side view. C. Plant with flower, in situ. Photographed by Sebastián Vieira from unvouchered specimens from the same population of the plant that served as type.

with Lepanthes culex Luer \& R.Escobar, L. habenifera Luer \& R.Escobar, L. skeleton Luer \& R.Escobar, L. stelidilabia Luer \& R.Escobar, L. venusta Luer \& R.Escobar, among others.
Phenology: Under greenhouse conditions on the outskirts of Medellin at $2700 \mathrm{~m}$ elevation, this species blooms all the year round. The flowers are frequently pollinated, producing capsules and propagating 
naturally on nearby pots. Pseudocopulatory pollination by fungus gnats of the Sciaridae family has been observed several times, with the male fly staying attached to the appendix of the lip of the flower for several minutes (Fig. 3).

Lepanthes sabinadaleyana is distinguished by its medium size plant with elongated, slender ramicauls, and tightly fitting, acuminate lepanthiform sheaths; an inflorescence borne resting on the adaxial surface of the leaf with intense rose flowers; transversely bilobed, pubescent petals, with triangular lobes, acute to subacute; a bilaminate lip with the blades diverging, thick, longitudinally concave, pubescent, and a small, obtuse, ovoid, pubescent appendix. Lepanthes lycocephala (Fig. 4B) is the most similar species from the central and western Andes of Colombia, with intense red flowers with pubescent petals and lip, the lip also with thick blades, longitudinally concave but it can be distinguished by having smaller, elliptical, subacute leaves suffused with purple on the abaxial surface and with erose margins (vs. narrowly ovate, acute, attenuate leaves with smooth margins in $L$. sabinadaleyana), transversely bilobed petals with the lower lobe narrowly oblong longer than the upper lobe ( $v s$. transversely bilobed petals, with both lobes triangular, acute to subacute in L. sabinadaleyana) and a bilaminate lip with obovate blades with the

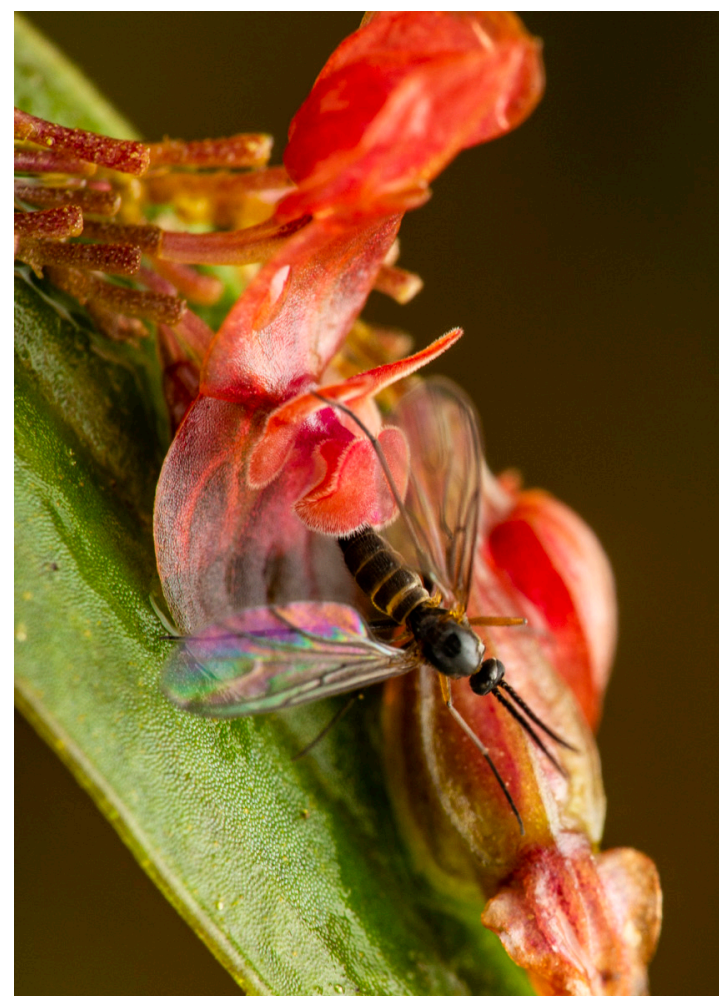

FIGURE 3. Flower of Lepanthes sabinadaleyana J.S.Moreno \& S.Vieira-Uribe with Sciaridae fungus gnat pseudocopulating with the flower. Photograph by Sebastián Vieira of an unvouchered specimen from the type locality.

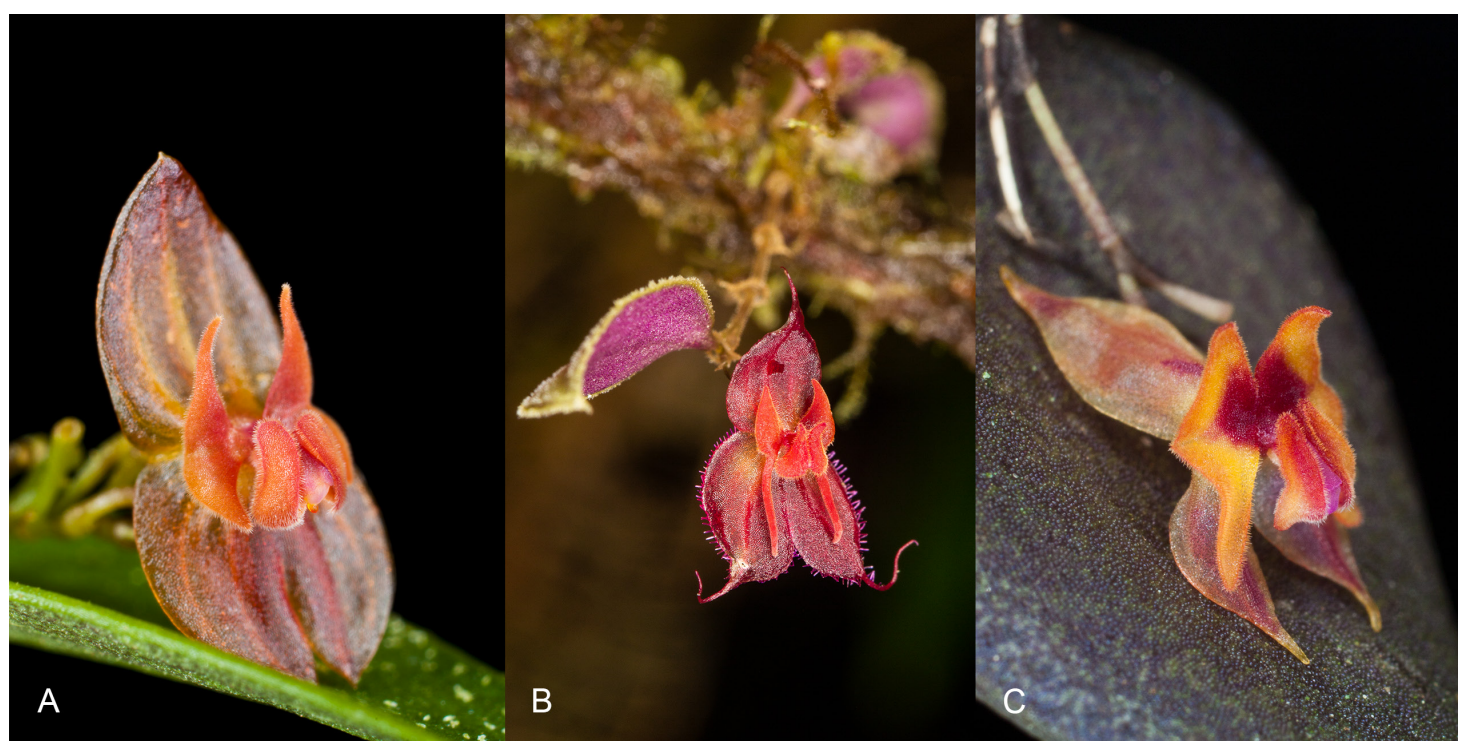

FIgURE 4. Comparison of the most similar species to Lepanthes sabinadaleyana J.S.Moreno \& S.Vieira-Uribe. A. Lepanthes sabinadaleyana. B. Lepanthes lycocephala. C. Lepanthes wageneri. Photographed by Sebastián Vieira. 
apices broadly subtruncate and without an appendix (vs. a bilaminate lip with the blades diverging, oblong-obovate with rounded apices and an obtuse, ovoid pubescent appendix in L. sabinadaleyana).

With wide distribution in the Andes from Venezuela to Bolivia, Lepanthes wageneri Rchb.f. (Fig. 4C) also has small flowers with a lip with the blades longitudinally concave but it can be easily differentiated from L. sabinadaleyana by the thick, elliptical leaves usually suffused with purple (vs. green, thinner, narrowly ovate, acute, attenuate leaves in L. sabinadaleyana), the inflorescence is shorter and borne on the abaxial surface of the leaf ( $v s$. resting on the adaxial surface of the leaf in L. sabinadaleyana), its flowers can have various combinations of yellow, orange, red and purple (vs. rose in L. sabinadaleyana) and a bilaminate lip with more or less oblong, cellular-pubescent blades with truncate apices and a cymbiform appendix ( $v s$. bilaminate lip with the blades diverging, oblong-obovate with rounded apices and an obtuse, ovoid pubescent appendix in $L$. sabinadaleyana).

Lepanthes exserta Luer \& Hirtz from Ecuador is also superficially similar to $L$. sabinadaleyana, but it can be easily distinguished by the column that protrudes forward and bearing the lip blades horizontally ( $v s$. not protruding column with lip blades longitudinally concave), the lip adnate to the column above the middle ( $v s$. adnate to the base of the column), and light green sepals (vs. translucent rose).

Lepanthes cissyana S.Vieira-Uribe \& J.S.Moreno, sp. nov. Fig. 5-6.

TYPE: Colombia. Antioquia: Municipality of Valdivia,

Ventanitas, La Esperanza Natural Reserve, $2150 \mathrm{~m}$, 2 Aug. 2017. J. S. Moreno 520, A. L. Erazo \& S. Vieira (holotype: JAUM; isotype: CAUP).

Diagnosis: This species is most similar to Lepanthes ballatrix Luer, but it is easily distinguished by its petals retuse between the two triangular lobes, and by the lip with the elliptical, oblique blades with truncate apices and with two appendices in the sinus.

Plant epiphytic, sympodial, caespitose herb up to $20 \mathrm{~cm}$ tall. Roots flexuous, filiform, $c a .1 \mathrm{~mm}$ in diameter. Ramicauls slender, suberect to horizontal, up to $19 \mathrm{~cm}$ long, enclosed by 10-13 lepanthiform sheaths. Leaf green with veins suffused with purple abaxially, suberect, lanceolate, thinly coriaceous, rugose between veins on the abaxial surface, the apex attenuate and tridentate, $8-9 \mathrm{~cm} \times 2.2-2.4 \mathrm{~cm}$, the rounded base contracted into a petiole $c a .6 \mathrm{~mm}$ long. Inflorescence a congested, successively flowered, distichous raceme shorter than the leaf, borne on the abaxial surface of the leaf, up to $3.8 \mathrm{~cm}$ long; peduncle filiform, terete, up to $2.7 \mathrm{~cm}$; floral bracts $c a .1 .4 \mathrm{~mm}$ long. Ovary costate, ca. $2 \mathrm{~mm}$ long. Flowers with yellow to saffron sepals, the lateral sepals suffused with red near the interior margin, the petals orange with red margins, the lip and column purple. Dorsal sepal triangular, acute, 3-veined, connate at the base to the lateral sepals for $c a .1 .5 \mathrm{~mm}, 3 \times 6 \mathrm{~mm}$. Lateral sepals ovate, oblique, acute, shortly acuminate, 2-veined, abaxially carinate along the mid vein, connate for $3.8 \mathrm{~mm}, 2.9 \times 6.2 \mathrm{~mm}$. Petals puberulent, transversely bilobed, retuse between the two lobes, $4.2 \times 1.3 \mathrm{~mm}, 1$-veined, the upper lobe ovate to triangular, oblique, obtuse; the lower lobe triangular, with one external basal undulation, subfalcate, oblique, subacute. Lip bilaminate, pubescent, blades touching above the column, elliptical, oblique, convex with recurved margins, the apices truncate, $1.4-1.5 \times 0.8-0.9 \mathrm{~mm}$, the connectives cuneate, the body semicircular, concave, connate at the base of the column, with two shortly oblong, long pubescent appendices, located at the sinus just below the apex of the column on both sides of the rostellum and viscidium. Column adpressed to the body of the lip, terete, ca. $1.5 \mathrm{~mm}$ long; anther apical, stigma ventral, bilobed, filling the lip body cavity. Pollinia 2, pyriform, attached to a detachable viscidium, $c a$. $0.5 \mathrm{~mm}$ long. Anther cap subquadrate, cucullate, 0.4 $\mathrm{mm}$ long. Capsule not seen.

Eponymy: Name honoring Cissy Mitchell. The right to name this species was given to John Mitchell, who generously donated land purchase funds for the expansion of the natural reserves where the species was found.

Habitat And ECOlogy: Lepanthes cissyana is so far endemic to the "Alto de Ventanas" ecoregion. It was first found in 2010 in Vereda La Candelaria, municipality of Yarumal, at 2200 m elevation growing on the moss-covered trunk of a fallen tree near the 


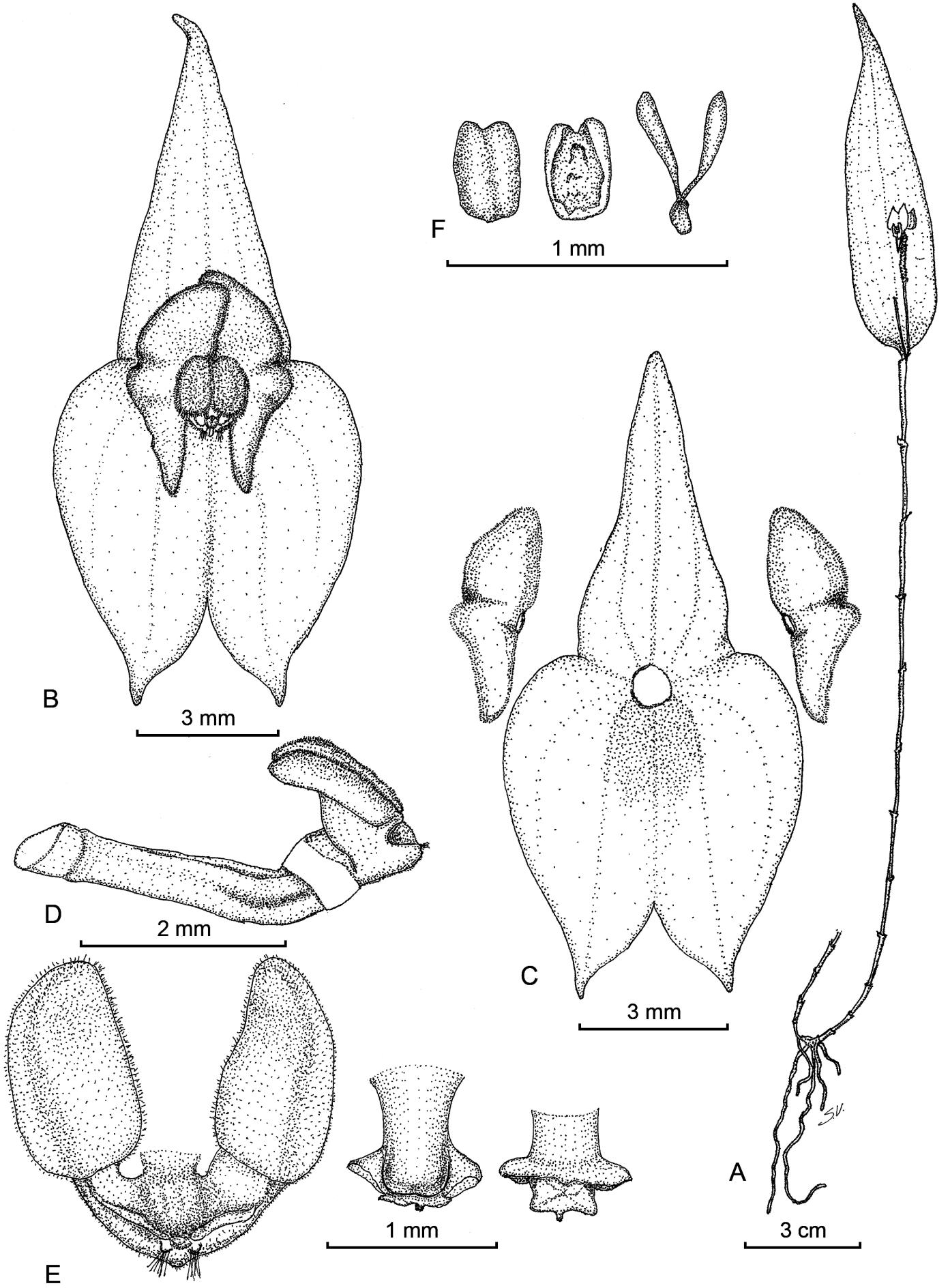

Figure 5. Lepanthes cissyana S.Vieira-Uribe \& J.S.Moreno. A. Habit. B. Flower. C. Dissected perianth. D. Ovary, column and lip, side view. E. Lip in expanded position, and column in dorsal and ventral view. F. Anther cap and pollinia. Drawn by Sebastián Vieira from the plant that served as type. 


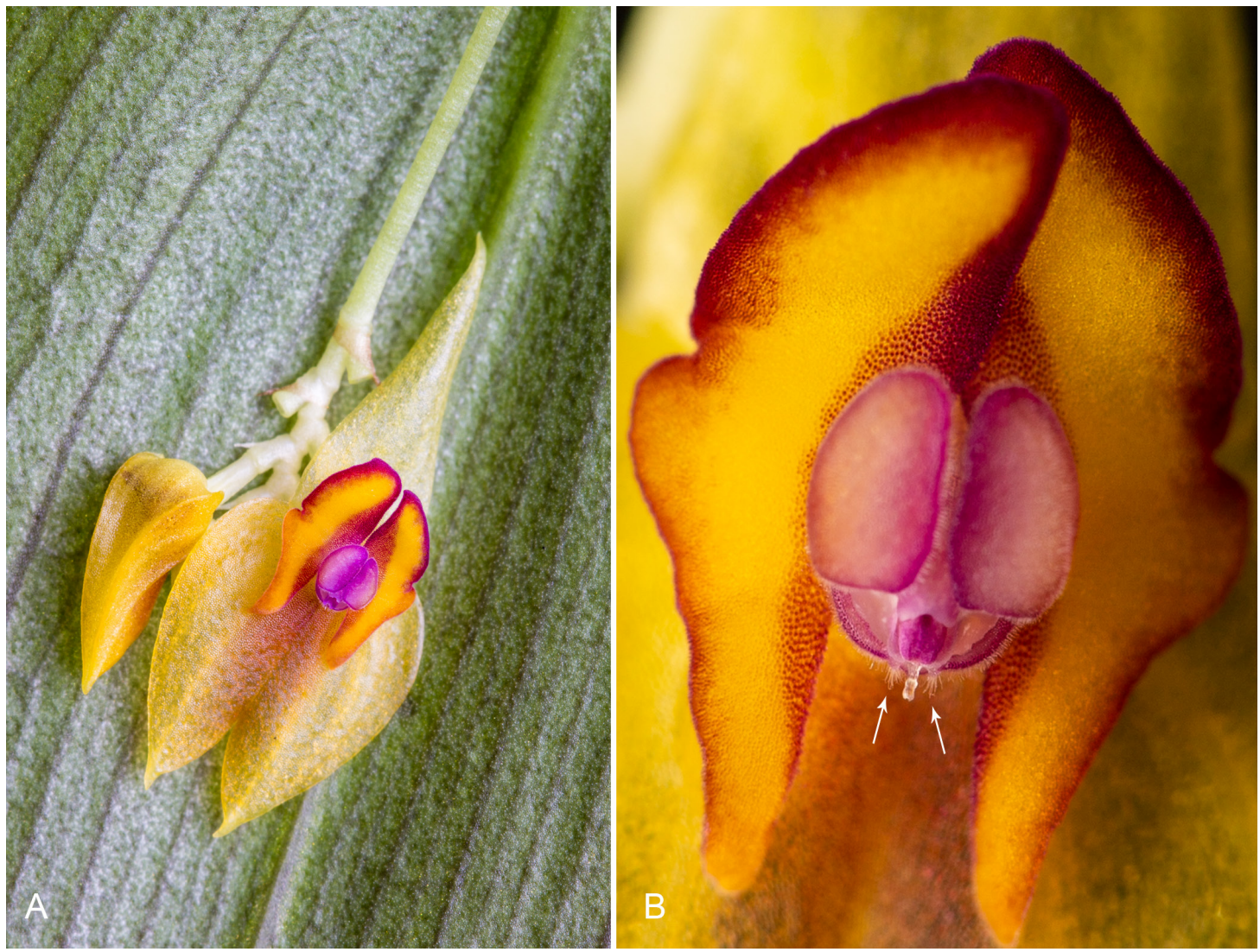

Figure 6. Lepanthes cissyana S.Vieira-Uribe \& J.S.Moreno. A. Flower. B. Detail of the flower, showing the two appendices, unique of this species. Photographs by Sebastián Vieira of the plant that served as type.

forest edge. Years later, when exploring the "La Esperanza" natural reserve located just $3 \mathrm{~km}$ away from the first locality, several plants were found also growing on moss-covered tree trunks, along the borders of a creek at $2150 \mathrm{~m}$ elevation. At this locality, Lepanthes cissyana grows close to other species of Lepanthes, including L. agglutinata Luer, L. janitor Luer \& R.Escobar, L. myoxophora Luer \& R.Escobar, L. sabinadaleyana J.S.Moreno \& S.Vieira-Uribe, $L$. skeleton Luer \& R.Escobar and L. stelidilabia Luer \& R.Escobar, among others, shaded by the forest canopy above the creek and receiving humidity from the nearby flowing water, the frequent fogs and rains.

Phenology: This species has been observed blooming at its habitat, in different months during consecutive years. It appears to bloom all year round.

This species is worthy of attention because of its purple lip with a concave, semi-circular body having two separate appendices; to date, a characteristic unique to this species. Its flowers are similar to other species having large yellow flowers borne on the abaxial surface of the leaf, with triangular dorsal sepals, ovate lateral sepals, and red-rimmed petals. Among these, Lepanthes cissyana is most similar to L. ballatrix from Ecuador (Luer \& Thoerle 2011), but is easily distinguished from it by its petals with the upper lobe ovate to triangular and the lower lobe triangular, with one external basal undulation ( $v s$. lobes suborbicular to broadly elliptical in L. ballatrix) and by the characteristic purple lip (vs. orange to red, more or less suffused with purple in L. ballatrix) with a semicircular body with two shortly oblong, long pubescent appendices in the sinus (vs. body broad with one triangular, concave, ciliate appendix in L. ballatrix).

Lepanthes cissyana is also similar to L. chrysina Luer \& Hirtz, L. cingens Luer \& R.Escobar, L. deutera Luer \& Thoerle and L. membranacea Luer \& Hirtz but 
can be easily distinguished by the purple lip having a semi-circular, concave body with two shortly oblong, long pubescent appendices, located in the sinus just below the apex of the column on both sides of the rostellum (Fig. 6B).

Lepanthes dougdarlingii S.Vieira-Uribe \& J.S.Moreno, sp. nov. (Fig. 7, 8, 9A, 10A).

TYPE: Colombia. Antioquia: Municipality of Valdivia, Ventanitas, La Esperanza Natural Reserve, $2150 \mathrm{~m}$, 2 Aug. 2017. J. S. Moreno 521, A. L. Erazo \& S. Vieira (holotype: JAUM; isotype: CAUP).

Diagnosis: Lepanthes dougdarlingii is similar to $L$. hortensis Luer \& R.Escobar, but is easily distinguished by its prolific habit; the lip with blades oblong to obovate, rounded, marginally ciliate and the appendix ligulate to oblong, saccate in the middle, with an apical gland-like structure.

Plant terrestrial, sympodial, caespitose, prolific herb up to $35 \mathrm{~cm}$ tall, caespitose and prolific. Roots slender, flexuous, filiform, ca. $1 \mathrm{~mm}$ in diameter. Ramicauls slender, erect, frequently producing additional ramicauls from the apex, up to $27 \mathrm{~cm}$ long, enclosed by 10-21, ribbed lepanthiform sheaths with minutely ciliate, long acuminate ostia. Leaf green to olive, horizontal, ovate, attenuate, coriaceous, carinate along the main vein on the abaxial surface, $2.0-4.5 \times 1.2-2.3 \mathrm{~cm}$, the rounded base contracted into a petiole $c a .2 \mathrm{~mm}$ long, the apex emarginate with an apiculus in the middle. Inflorescence a congested, successively-flowered, distichous raceme shorter than the leaf, borne from either surface of the leaf, up to $2.6 \mathrm{~cm}$ long, with the flowers usually hanging on one side of the leaf; peduncle filiform, up to $2 \mathrm{~cm}$; floral bracts ca. $1.6 \mathrm{~mm}$ long. Ovary costate, $2.3 \mathrm{~mm}$ long. Flowers with amber sepals suffused with rust along the veins, fulvous petals suffused with rust along the mid vein and along two lines radiating from the base on both sides of the mid vein, the white lip suffused with mauve along the blade margins; dorsal sepal triangular-ovate, margins denticulate, attenuate, 3 -veined, abaxially carinate along the veins, connate at the base to the lateral sepals for ca. $1.9 \mathrm{~mm}, 6.9$ $\times 4.7 \mathrm{~mm}$; lateral sepals ovate, margins denticulate, shortly acuminate, 2 -veined, abaxially carinate along the veins, connate for ca. $2 \mathrm{~mm}, 6 \times 3 \mathrm{~mm}$. Petals transversely bilobed with a small, rounded marginal lobe at the apex, $1.2 \times 4.3 \mathrm{~mm}$, the upper lobe oblong, short pubescent, truncate, the apex with a small tooth-like lobe near the interior margin, $2 \mathrm{~mm}$ long; the lower lobe triangular, sigmoid, pubescent, acute, $2.3 \mathrm{~mm}$ long. Lip bilaminate, the blades adherent medially above the column, oblong to obovate, membranous, the margins ciliate, rounded, $2.2 \times 0.8$
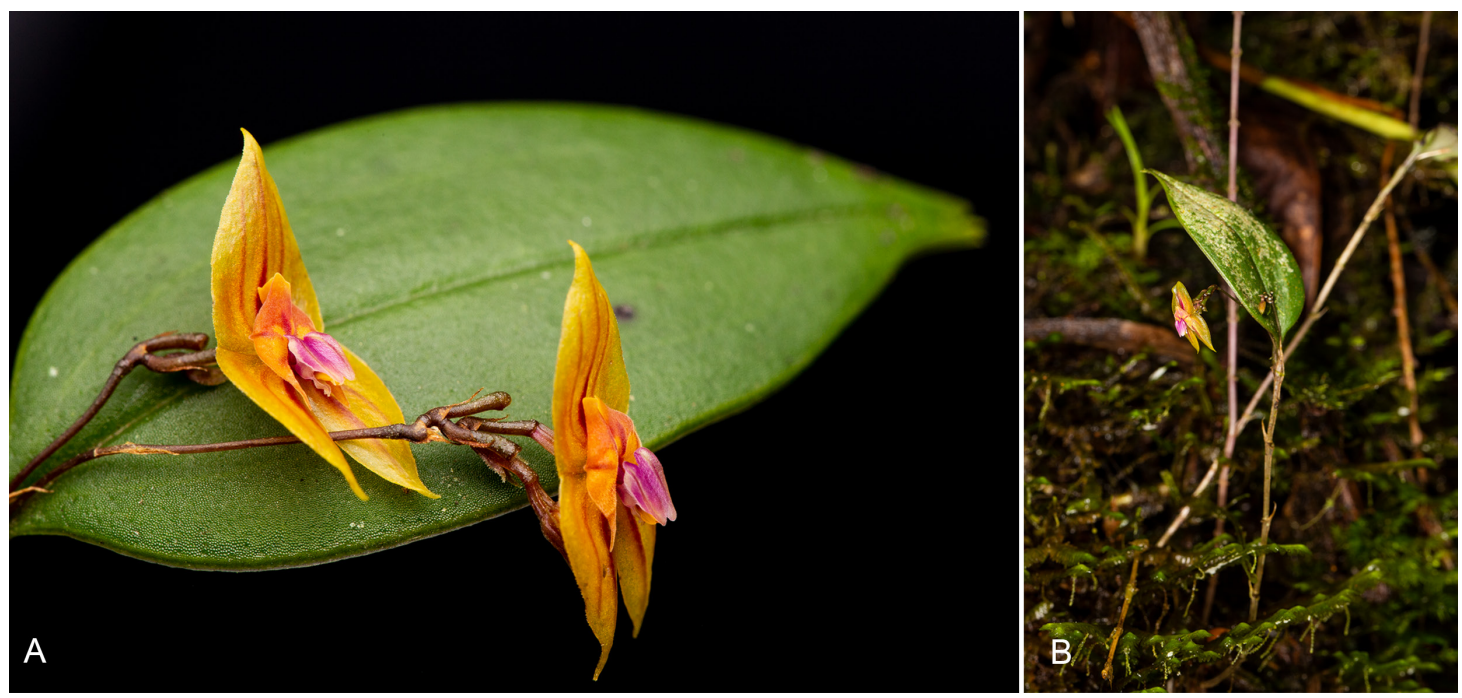

Figure 7. Lepanthes dougdarlingii S.Vieira-Uribe \& J.S.Moreno. A. Leaf with flowers. B. Habitat and Plant. Photographs by Sebastián Vieira from the plant that served as type. 


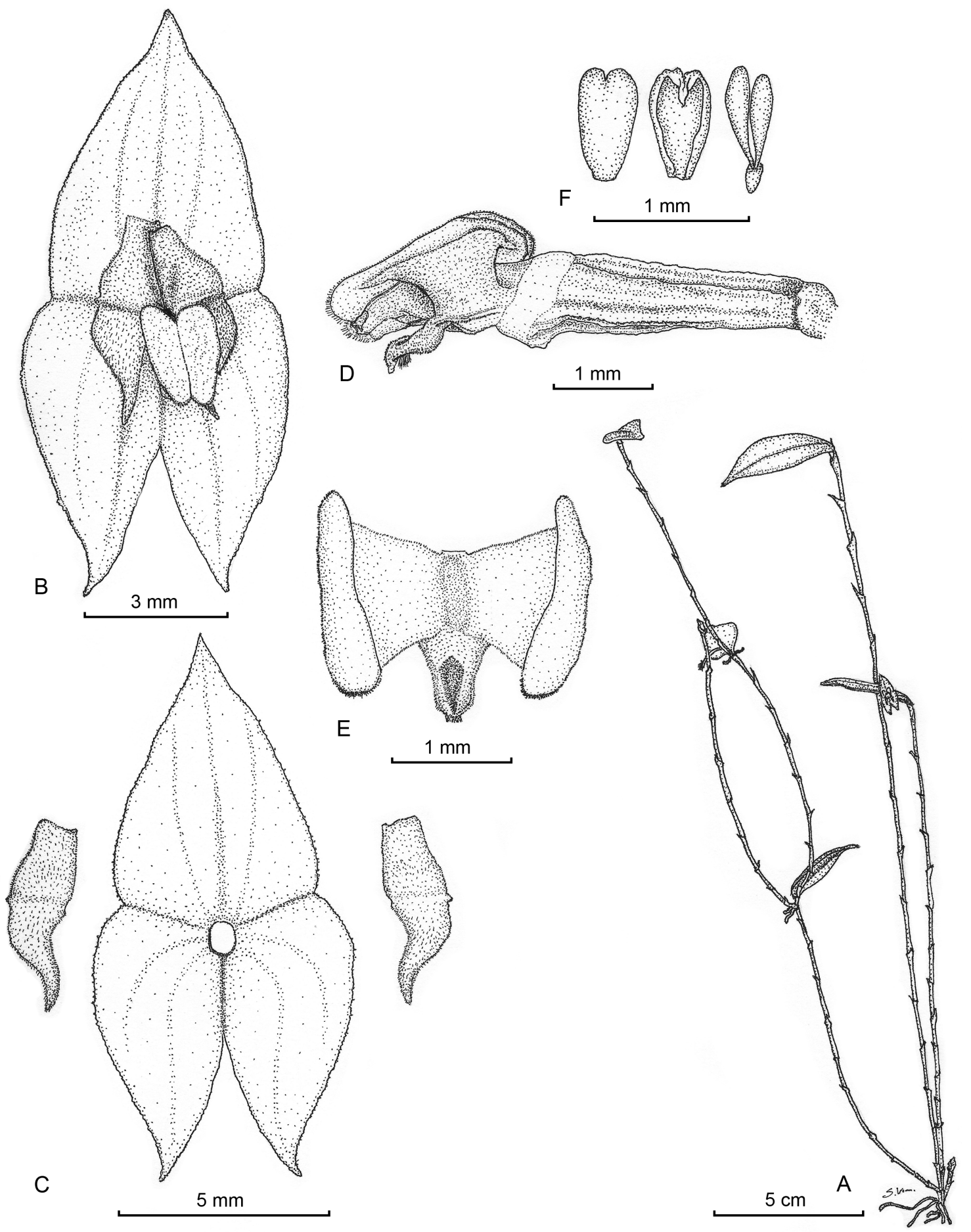

Figure 8. Lepanthes dougdarlingii S.Vieira-Uribe \& J.S.Moreno. A. Habit. B. Flower. C. Dissected perianth. D. Ovary, column and lip, lateral view. E. Lip in expanded position. F. Anther cap and pollinia. Drawn by Sebastián Vieira from the plant that served as type. 


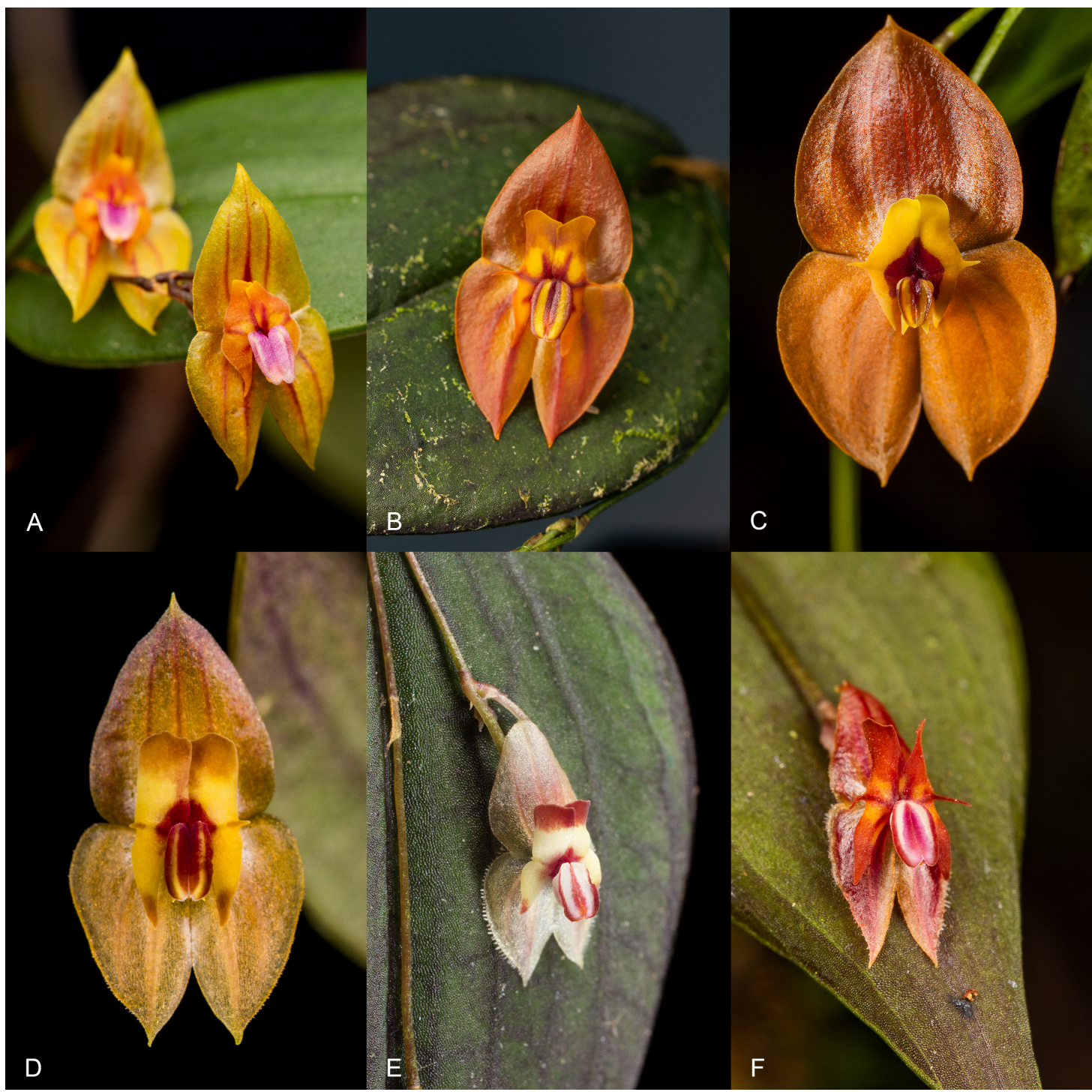

FIgure 9. Comparison of Lepanthes dougdarlingii with some of the most similar species. A. Lepanthes dougdarlingii. B. Lepanthes hortensis. C-D. Lepanthes ophelma. E. Lepanthes cactoura. F. Lepanthes habenifera. Photographs by Sebastián Vieira.

$\mathrm{mm}$, the connectives cuneate, the body subquadrate, adnate to the base of the column; appendix ligulate to oblong, pubescent, saccate in the middle, with an apical gland-like structure and a tuft of hairs on the abaxial surface near the apex, ca. $0.7 \mathrm{~mm}$ long. Column terete, capitate, ca. $1.9 \mathrm{~mm}$ long; anther apical, stigma ventral. Pollinia 2, pyriform, attached to a detachable viscidium, ca. $0.7 \mathrm{~mm}$ long. Anther cap cordate, cucullate, ca. $0.7 \mathrm{~mm}$ long. Capsule not seen.
Eponymy: Name in remembrance of Doug Schwartz, a dear American friend who had a passion for life, beauty, nature, and the brilliance and warmth of the color orange. The right to name this species was given to Ann Kaupp, who generously donated land purchase funds for the expansion of the natural reserves where the species was found.

Habitat and ECOLOgy: Lepanthes dougdarlingii has been found only inside the "La Esperanza" natural 

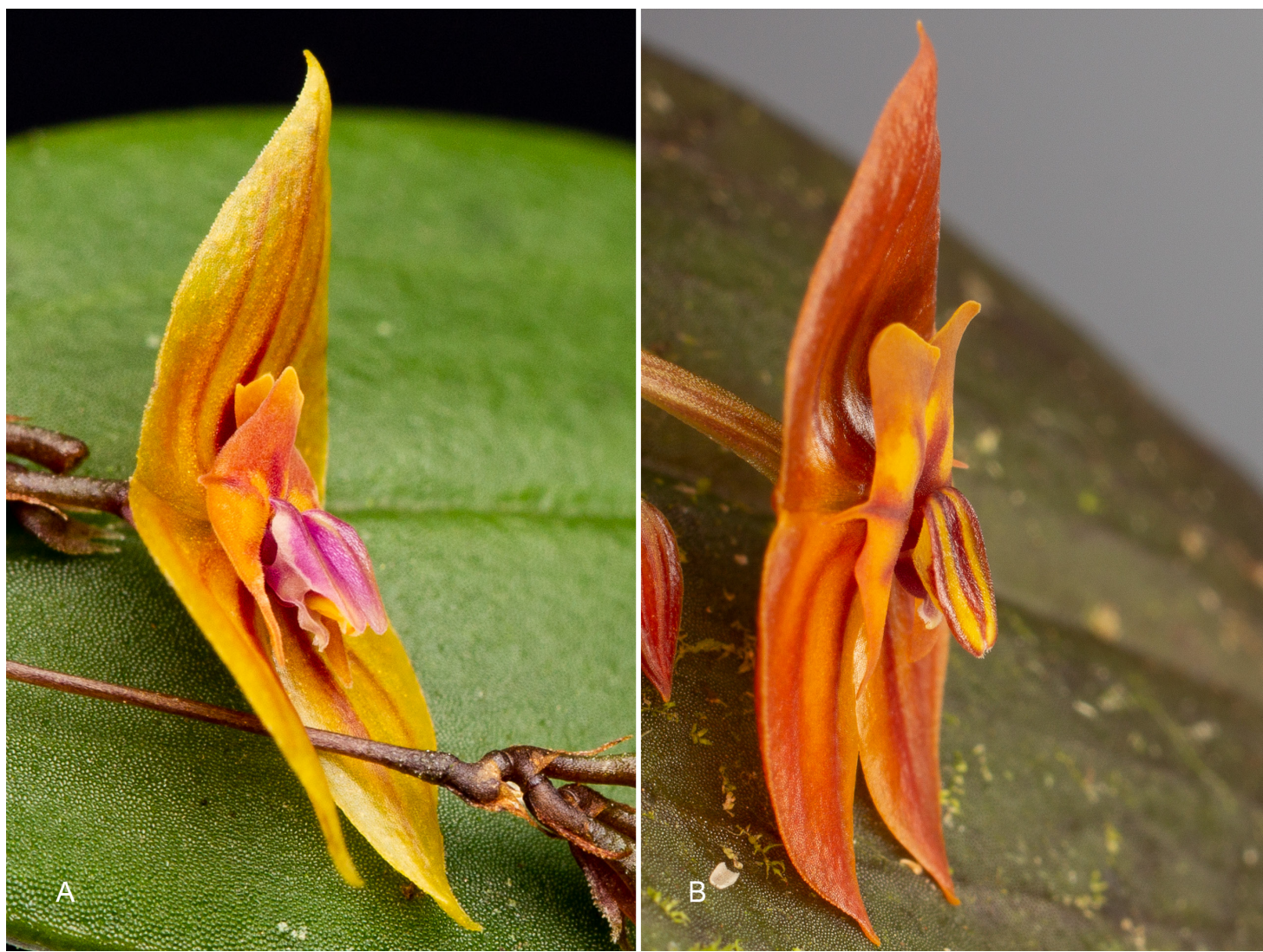

FIgURE 10. Comparison of the flower of $L$. dougdarlingii with the most similar species, L. hortensis, with a detailed view of the petals and lip appendix. Photographs by Sebastián Vieira.

reserve, always growing as a terrestrial on moss and leaf litter covered soil near the roots of shrubs and trees, always growing under shaded and very humid conditions (Fig. 7B). It seems to prefer disturbed areas inside the forest, near the trails, where its prolific habit allows it to climb the nearby intermingled twigs and plants. It grows between 2100 and 2200 m elevation.

Phenology: L. dougdarlingii has been observed blooming on almost every month of the year, then, it is presumed to bloom all year round.

This new species is remarkable for its large, colorful flowers which frequently hang over the sides of the leaves, and also for its prolific habit. The flowers are similar to other large, colorful flowered species with the lip blades adherent over the column and a small marginal lobe between the two lobes of the petals. Among these, Lepanthes dougdarlingii is most similar to L. hortensis (Fig. 9B, 10B) and $L$. ophelma Luer \& R.Escobar (Fig. 9C, 9D), but can be easily differentiated from them by the petals with the lower lobe triangular, sigmoid and acute, the small and rounded marginal middle lobe; the white lip, suffused with mauve, with the adherent blades oblong to obovate, with the ciliate margins, and the rounded apex; the appendix lingulate to oblong, pubescent, saccate in the middle, with an apical gland, and a tuft of hairs on the abaxial surface near the apex.

Other similar species include Lepanthes aristata Luer \& R.Escobar, L. cactoura Luer \& R.Escobar (Fig. 9E), L. habenifera Luer \& R.Escobar (Fig. 9F), L. macrantha Garay, L. quandi Luer \& R.Escobar and L. spelynx Luer \& R.Escobar, also with colorful flowers with adherent lip blades and petals with a marginal mid-lobe (Luer \& Thoerle 2012), but from all of them, L. dougdarlingii can be easily distinguished by growing as a terrestrial and having a prolific habit. 
Conservation status: The three new species were found inside one of the natural reserves of Corporación Salvamontes de Colombia, located in the "Alto de Ventanas" ecoregion, an area recently declared by the local government as an Integrated Management District. Due to the protection of the Natural Reserve, we do not consider any of them to be under risk of extinction and suggest classifying the three species under the IUCN category of "Data Deficient" because we don't have enough information to make a direct or indirect assessment, based on their distribution and/or population status.
AcKNowledgements. The authors thank Carlos Mauricio Mazo and Corporación Salvamontes Colombia for making possible this research at their natural reserves, the Rainforest Trust for their support to this research; Bruno Larsen, Mark Wilson, and the anonymous reviewers for their helpful revision of this manuscript; the curators and the staff at Jardín Botánico Joaquín Antonio Uribe (JAUM) and University of Cauca Herbarium (CAUP) for their support. We also thank Adam Deaton, John Mitchell, Ann Kaupp, The Rainforest Trust and the Orchid Conservation Alliance for their interest and support on preserving the habitat of the new species described here, and as a consequence, of many more rare and endangered fauna and flora species living at the same place.

\section{LITERATURE CITED}

Bernal, R., Gradstein, S. R. \& Celis, M. (2015). Catálogo de plantas y líquenes de Colombia. Bogotá, Colombia: Instituto de Ciencias Naturales, Universidad Nacional de Colombia. Accesado en http://catalogoplantasdecolombia.unal.edu.co

Costello, M. J., Vanhoorne, B. \& Appeltans, W. (2015). Conservation of biodiversity through taxonomy, data publication, and collaborative infrastructures. Conservation Biology, 29(4), 711-719.

Dubois, A. (2003). The relationships between taxonomy and conservation biology in the century of extinctions. Comptes Rendus Biologies, 326 (1), 9-21.

Luer, C. A. \& Escobar, R. (1984). New Lepanthes species from Colombia - 2. American Orchid Society Bulletin, 53(1), 30.

Luer, C. A. \& Escobar, R. (1984a). New Lepanthes species from Colombia - 2. American Orchid Society Bulletin, 53(3), 261.

Luer, C. A. \& Escobar, R. (1984b). New Lepanthes species from Colombia - 2. American Orchid Society Bulletin, 53(4), 368.

Luer, C. A. \& Escobar, R. (1984c). New Lepanthes species from Colombia - 2. American Orchid Society Bulletin, 53(6), 604-611.

Luer, C. A. \& Thoerle, L. (2011). Lepanthes Sw. and affiliates. In C. Persson \& B. Stahl, Flora of Ecuador, 88, 13-405. Goteborg: Botanic Institute, Goteborg University.

Luer, C. A. \& Thoerle, L. (2012). Icones Pleurothallidinarum XXXII, Lepanthes of Colombia (Orchidaceae). Monographs in Systematic Botany from the Missouri Botanical Garden, 123, 1-296.

Orejuela, J. E. (2012). Orchids of the cloud forests of southwestern Colombia and opportunities for their conservation. European Journal of Environmental Sciences, 2(1), 19-32. 
